
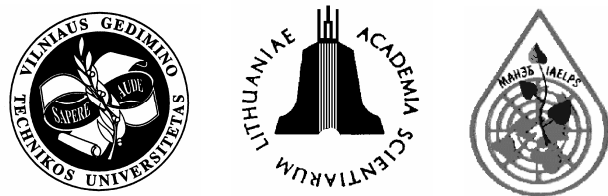

\title{
SORPTION OF COPPER (II) AND NONIONIC SURFACTANT BY ION EXCHANGERS AND ACTIVATED CARBON
}

\author{
Renata Jancevičiūtè ${ }^{1}$, Audronė Gefenienè $\dot{e}^{1,2}$ \\ ${ }^{1}$ Dept of Chemistry, Vilnius Pedagogical University, Studentu g. 39, LT-08106 Vilnius, Lithuania. \\ ${ }^{2}$ Dept of Ecological Chemistry, Institute of Chemistry, A. Goštauto g. 9, LT-01108 Vilnius, Lithuania. \\ E-mail:audronege@vpu.lt
}

Submitted 21 Apr 2006; accepted 10 Oct 2006

\begin{abstract}
Ion exchange resins, which are widely used for the removal of copper (II) ions from effluents, can also sorb nonionic surfactants entering into the wastewater with copper (II) ions simultaneously after various industrial processes. The study of equilibrium sorption of copper (II) and nonionic surfactant Lutensol AO-10 under laboratory conditions by different types of ion exchangers and activated carbon has shown that the Purolite S950 chelating ion exchanger has the highest sorption capacity for copper (II) ions. Ion exchangers with carboxylic functional groups demonstrate the highest affinity for nonionic surfactant. Purolite C107E weak acid cation exchanger could be suitable for the cosorption of copper (II) ions and nonionic surfactant Lutensol AO-10. Kinetic study of this ion exchange resin leads to a conclusion that the sorption of copper (II) ions was a fast process, and after $30 \mathrm{~min}$ the equilibrium was attained. When the concentration of copper (II) solution decreases, difference between the sorption capacity of various ion exchangers decrease. The influence of nonionic surfactant on the sorption of copper (II) is insignificant.
\end{abstract}

Keywords: ion exchange resin, activated carbon, sorption, copper, nonionic surfactant, removal efficiency.

\section{Introduction}

Heavy metals discharged to the environment as industrial waste cause serious soil and water pollution. They cannot be biodegraded and thus can follow a number of different pathways. The metals can adsorb on to the soil, runoff into rivers or leach in the ground water [1]. Copper ions and surfactants exhibit high acute and high chronic toxicity to aquatic organisms [2]. In humans copper can cause serious kidney and liver damage. Copper (II) salts are widely used in textile dyeing, electroplating process, as pigments for glass and ceramics, etc. In some cases they are used with nonionic surfactants acting as wetting, degreasing and emulsifying agents. The use of surfactants is gradually increasing in textiles, fibers, food, paints, polymers, pharmaceuticals, oil recovery. The textile industries alone consume about $10 \%$ of the world surfactant production, and the wastewater of these industries contains high concentration of surfactant [3]. The removal of copper ions and organic contaminants including nonionic surfactants from aqueous solutions is a problem frequently encountered in the treatment of industrial wastewaters. Surfactants are responsible for causing foams in rivers and effluent treatment plants. The removal of nonionic surfactants is important not only because of their toxicity, but also for their biodegradation metabolites that are more persistent than their parent compounds [4]. Now there is a growing need for an efficient and cost-effective process for the removal of heavy metals as well as nonionic surfactants. The application of different methods has been reported. The purification of water from nonionic surfactants can be performed by the biosorption process using activated carbon as a carrier of biofilm [5]. Modified materials of natural origin, such as cellulose and kaolinite clays as well as commercial polymers (hydrogel sorbent based on crosslinked polyacrylic acid, Favor SXM 9130 and Amberlite IRA410 strong anion exchange resin), were used as sorbents for the removal of surfactants [6]. For the reduction of concentration of nonionic surfactant Rokafenol N-8 (ethoxylated phenol) in aqueous solution (industrial waste water) polymers containing tertiary amino or quaternary ammonium groups have been prepared by solution- suspension polymerization. Polymers containing quaternary ammonium salts, which were more hydrophobic, appeared to be more effective sorbents of nonionic surfactant [7]. Heavy metals are common pollutants, and they must be removed if present at concentration higher than required by the environmental regulations. Heavy metal removal by chemical coagulation and precipitation is performed [8]. Various types of waste biomass, including bacteria, yeast, fungi and marine algae, were found to be potential for use in the heavy metal removal process [9]. The adsorption of several low-cost adsorbents, such as biopolymers, has been investigated. Among these biopolymers, chitosan has proved to be a promising material [10]. The sorbing properties of activated carbon for heavy metal ions at different conditions was characterized assuming that it takes place by formation of complexes with functional groups, present in the activated carbon [11]. Ion exchange 
resins can also make an active contribution to environmental protection. The reversible nature of ion exchange and sorption processes make them particularly suitable with regard to economic aspects and pollution control [12]. Ion exchange technology is well established for the sorption of copper ions. However, the ion exchange resins usually used for the retention of charged particles in some cases demonstrate the affinity towards nonionic compounds. There is a possibility to remove copper ions and nonionic surfactant simultaneously [13, 14].

The objective of this work was to elucidate the effectiveness of various types of ion exchangers and activated carbon for simultaneous sorption of copper (II) and nonionic surfactant (oxyethylated alcohols Lutensol AO10) and to evaluate the effect of nonionic surfactant on the retention of metal ions. The second objective was to investigate the kinetics of copper (II) sorption using microscopic technique.

\section{Materials and methods}

The resins used were chosen to cover a range of their different types available, i e strong and weak acid cation exchangers, various chelating resins and strong basic anion exchanger. For comparison, a parallel test with commercial activated carbon was carried out. Details of the sorbents are given in Table 1. All resins were used in the ionic form as supplied. To identify the best ion exchange resin for the sorption of the two contaminants a laboratory test was performed with model solutions prepared from the copper (II) chloride dihydrate and nonionic surfactant Lutensol AO-10. Lutensol AO-10 is a mixture of linear polyoxyethylene alcohols of the form

$$
\mathrm{C}_{m} \mathrm{H}_{2 m+1}-\left(\mathrm{OC}_{2} \mathrm{H}_{4}\right)_{n} \mathrm{OH} \text {, }
$$

where the alkyl chain length (m) is varied, with $m=13-15$ and the polyoxyethylene chain length (n) fixed at 10 , an average relative molecular mass, $M_{r}=654$. The molecules of nonionic surfactant possess both a hydrophobic and hydrophilic regions. Nonionic surfactants owe their solubility to hydration of the polyoxyethylene moiety. At a concentration higher than their critical micellar concentration (cmc) they form aggregates. The micelles consist of a spherical hydrocarbon core and an outer spherical shell of polyoxyethylene chains. The critical micellar concentration was determined by surface tension technique. The cmc value is taken as the molar concentration at the intersection of two linear parts of relationship between surface tension and $\ln$ c. [15]. For Lutensol AO10 , it was found to be $1,4 \times 10^{-3} \mathrm{~mol} / \mathrm{L}$ (Fig 1).

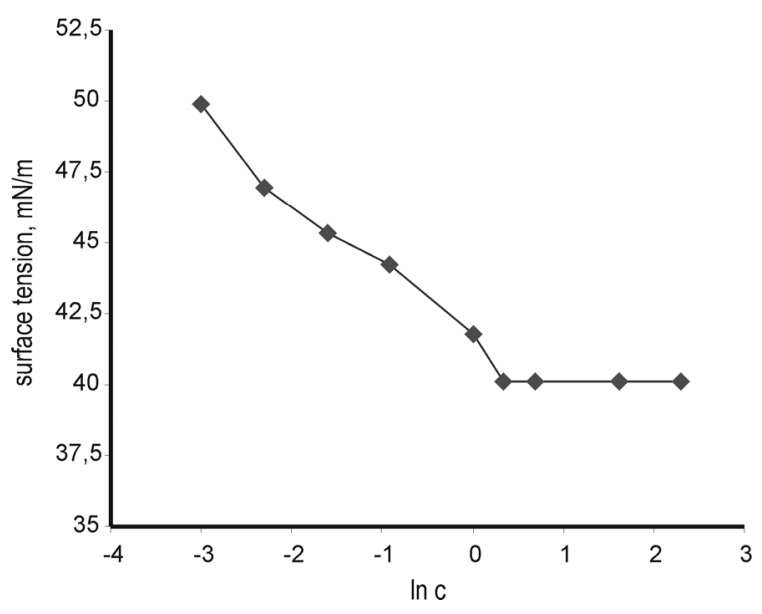

Fig 1. Surface tension values of nonionic surfactant Lutensol AO-10 solutions as a function of surfactant concentration $(\mathrm{mmol} / \mathrm{L})$

A series of batch equilibrium tests was carried out using solutions with initial concentration of copper 1 and $10 \mathrm{mmol} / \mathrm{L}$. An equimolecular mixture of copper (II) and Lutensol AO-10 was used for the investigation of cosorption. The solutions were prepared by dissolving appropriate amounts of materials in distilled water. The $\mathrm{pH}$ values of initial solutions were measured without further adjustment. After sorption they were rechecked and decrease in solution $\mathrm{pH}$ was determined in the case of hydrogen form of ion exchanger. Preliminary kinetic experiments were completed to establish the time required for the sorption system to reach equilibrium. The sorption of copper was relatively fast, however, five days were needed for attainment of equilibrium with Lutensol AO-10. The solid-liquid ratio was of $200 \mathrm{ml}$ of solution per $g$ of dry resin. The concentration of copper (II) ions was determined complexometrically with EDTA disodium salt using murexide [16]. A spectrophotometric method was used for determination of surfactant [15]. The amounts of copper (II) and Lutensol AO-10 sorbed were calculated as follows:

Table 1. Ion exchange resins and activated carbon tested

\begin{tabular}{c|c|c|c|c|c}
\hline Sorbent & Commercial name & Structure & Pores & Functional group & Form of resin \\
\hline 1 & Purolite C160 & polystyrene & macroporous & sulfonic acid & $\mathrm{H}^{+}$ \\
\hline 2 & Activated carbon & granulated & & & \\
\hline 3 & Purolite S940 & polystyrene & macroporous & aminophosphonate & $\mathrm{Na}^{+}$ \\
\hline 4 & Purolite A420S & polystyrene & gel & quaternary ammonium & $\mathrm{Cl}^{-}$ \\
\hline 5 & Purolite C115E & polymethacrylic & macroporous & carboxylic acid & $\mathrm{H}^{+}$ \\
\hline 6 & Purolite C107E & polyacrylic & macroporous & carboxylic acid & $\mathrm{H}^{+}$ \\
\hline 7 & Purolite S950 & polystyrene & macroporous & aminophosphonate & $\mathrm{Na}^{+}$ \\
\hline 8 & Purolite C104 & polyacrylic & macroporous & carboxylic acid & $\mathrm{H}^{+}$ \\
\hline 9 & Purolite S920 & polystyrene & macroporous & thiourea & $\mathrm{H}^{+}$ \\
\hline 10 & Purolite C106 & polyacrylic & macroporous & carboxylic acid & $\mathrm{H}^{+}$ \\
\hline
\end{tabular}




$$
A=\left(C_{0}-C\right) \mathrm{V} / \mathrm{m}
$$

where $C_{0}$ is the initial solution concentration $(\mathrm{mmol} / \mathrm{L}), C$ the final solution concentration $(\mathrm{mmol} / \mathrm{L}), V$ the volume of the solution (L), $m$ the dry cation exchanger or activated carbon mass (g) and $A$ the sorption capacity (mmol/g) defined as amount of contaminant sorbed (mmol) per mass of the sorbent applied $(\mathrm{g})$. The degree of removal (removal efficiency) was calculated according to the formula:

$$
E=\left\{\left(C_{0}-C\right) / C_{0}\right\} \times 100,
$$

where $C_{0}$ - the initial solution concentration $(\mathrm{mmol} / \mathrm{L})$, $C$ - the final solution concentration $(\mathrm{mmol} / \mathrm{L}), E-$ the degree of removal. All the values are the mean of three independent observations.

To carry out the kinetic experiment, copper (II) solution of $10 \mathrm{mmol} / \mathrm{L}$ was contacted with the particles of Purolite C107E cation exchanger. The sorption rate was determined by measuring the concentration of copper (II) at different time intervals. Small volumes (less than $2 \mathrm{ml}$ ) of samples were collected from the solution and analysed. During sorption, at each time interval, one particle was taken out from the solution. Afterwards, it was cut using a scalpel and then photographed using a camera installed in the microscope.

\section{Results and discussion}

To determine the performance of all the ion exchangers chosen, the sorption capacity $(A, \mathrm{mmol} / \mathrm{g})$ was evaluated for copper (II) and nonionic surfactant Lutensol AO-10 removal. The resulting data of equilibrium sorption are shown in Fig 2. The experimental results indicate that the Purolite S950 and Purolite S940 chelating resins have a great capacity for removal of copper. Copper (II) as the Lewis acid metal interacts with these resins by ionexchange and also by a coordination mechanism. Using the chelating ion exchangers a high degree of copper (II) removal was attained (Table 2), although the retention of copper (II) was not sufficient in the case of Purolite S920 chelating resin with thiourea functional groups. The reason of a low copper (II) sorption can be not only the nature of functional groups, but also the hydrogen form of this chelating resin. The Purolite C160 strong acid resin showed much higher copper loading than weak acid resins in hydrogen form under the given conditions (mildly acidic solution) because of a limited ionization of carboxylic functional groups when compared to sulphonic ones. A low capacity of the Purolite A420S anion exchanger for copper cations resulted from a positive charge of functional groups making the action of electrostatic attractive forces impossible. As it is clear from Fig 2, activated carbon is also capable of sorbing copper (II) ions due to the porous structure and, presumably, due to the chemical nature of the surface. On the other hand, when chelating resins (Purolite S950 and Purolite S940) were applied to remove both contaminants (copper (II) and Lutensol AO-10) from the mixture of their solutions, the sorption of nonionic surfactant was relatively low (Fig 3).

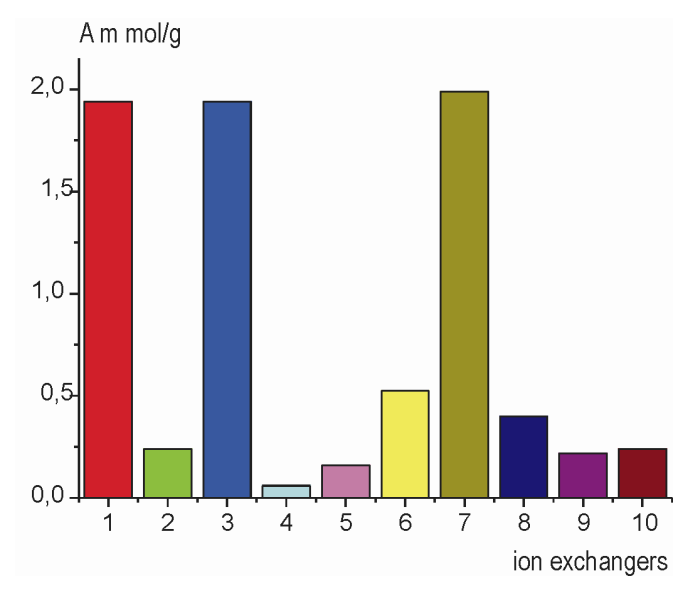

Fig 2. Sorption capacity (A) of sorbents tested for copper (II) ions at initial solution concentration of $10 \mathrm{mmol} / \mathrm{L}$

Table 2. Degree of copper (II) removal from aqueous solution $(10 \mathrm{mmol} / \mathrm{L})$

\begin{tabular}{c|c|c}
\hline Sorbent & Commercial name & Degree of removal (\%) \\
\hline 1 & Purolite C160 & 97,0 \\
\hline 2 & $\begin{array}{c}\text { Activated carbon } \\
\text { AC-20 }\end{array}$ & 12,0 \\
\hline 3 & Purolite S940 & 97,0 \\
\hline 4 & Purolite A420S & 3,0 \\
\hline 5 & Purolite C115E & 8,0 \\
\hline 6 & Purolite C107E & 21,3 \\
\hline 7 & Purolite S950 & 99,5 \\
\hline 8 & Purolite C104 & 20,0 \\
\hline 9 & Purolite S920 & 11,0 \\
\hline 10 & Purolite C106 & 12,0 \\
\hline
\end{tabular}

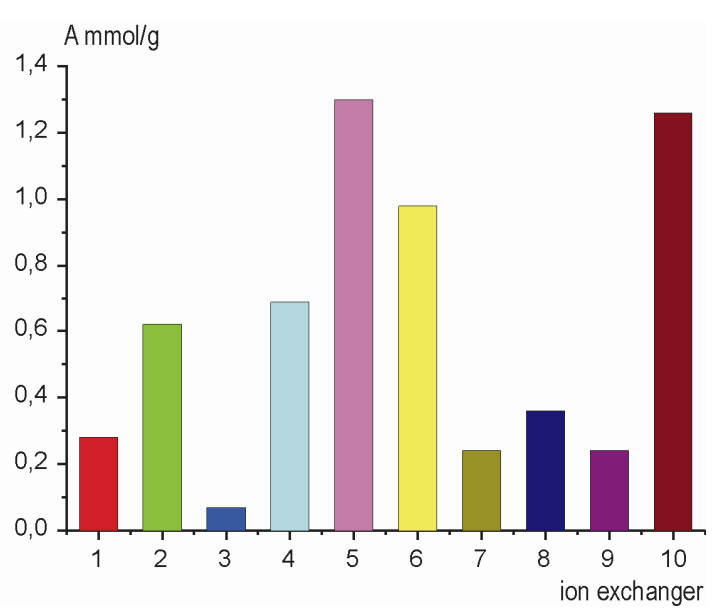

Fig 3. Sorption capacity (A) of sorbents tested for nonionic surfactant Lutensol AO-10 from equimolar mixture of copper (II) and nonionic surfactant at initial solution concentration of $10 \mathrm{mmol} / \mathrm{L}$

Chelating resins proved to be unsuitable for the simultaneous removal of copper (II) and Lutensol AO-10. The sorption of nonionic surfactant was the highest for weak acid cation exchangers. It can be explained by formation of hydrogen bonding between oxygen atoms in the 
oxyethylene groups contained in the surfactant and hydrogen atoms of the unionized carboxylic groups in the cation exchanger [11]. The presence of Lutensol AO-10 did not interfere in the sorption of copper (II). The sorption occurs with no significant change and only a slight drop in the sorption of copper (II) was observed, presumably, because of occupancy of the binding sites by the large molecules of Lutensol AO-10. However, the sorption of copper from the mixture by Purolite A420S anion exchanger was higher when compared to the sorption from single copper (II) solution, possibly due to the association with surfactant micelles. Further investigations are necessary to reveal more details about various types of interaction between the copper (II) ions, the functional groups of ion exchange resins and the nonionic surfactant. Water is an unfavourable solvent for the complexation of polyoxyethylene compounds with metal ions because of its increased ability to solvate ions [17]. However, interaction between ions and polyoxyethylene compounds possibly does occur in the water phase, and the ether linkages act as ligands for the cations [18]. Inorganic additives affect the nonionic surfactant solutions changing the micellar molecular weights and aggregation numbers. This problem has attracted a number of researchers. At the same time it should be mentioned that some questions concerning the mechanism of complexation remain unsolved.

Different behaviour of the investigated resins with respect to nonionic surfactant is very evident in Fig 2 which clearly shows the superiority of the Purolite C115E, Purolite C107E and Purolite C106 ion exchangers in removing nonionic surfactant. Their affinity towards nonionic surfactant is higher when compared to activated carbon, and they can sorb about $0,8 \mathrm{~g}$ of Lutensol AO-10 per $1 \mathrm{~g}$ of sorbent, although the removal efficiency as high as in the case of copper (II) was not achieved (Table 3).

Table 3. Degree of nonionic surfactant Lutensol AO-10 removal from solutions with copper (II) ions at initial solution concentration of $10 \mathrm{mmol} / \mathrm{L}$

\begin{tabular}{c|c|c}
\hline Sorbent & Commercial name & Degree of removal (\%) \\
\hline 1 & Purolite C160 & 14,0 \\
\hline 2 & $\begin{array}{c}\text { Activated carbon } \\
\text { AC-20 }\end{array}$ & 31,0 \\
\hline 3 & Purolite S940 & 4.0 \\
\hline 4 & Purolite A420S & 35,0 \\
\hline 5 & Purolite C115E & 65,0 \\
\hline 6 & Purolite C107E & 49,0 \\
\hline 7 & Purolite S950 & 12,0 \\
\hline 8 & Purolite C104 & 18,0 \\
\hline 9 & Purolite S920 & 12,0 \\
\hline 10 & Purolite C106 & 63,0 \\
\hline
\end{tabular}

It is difficult to explain a relatively low sorption capacity of Purolite C104 ion exchanger bearing the same carboxylic functional groups as the most efficient sorbents for nonionic surfactant. As can be seen from Fig 3 all types of ion exchange resins demonstrate capability of sorbing at least a small amount of nonionic surfactant.
This can be explained as a result of hydrophobic interaction between the nonpolar radical of Lutensol AO-10 molecule and the matrix polymer of the ion exchange resin.

The sorption capacity of ion exchangers for copper (II) ions was also investigated as a function of initial solution concentration (Fig 4). A series of batch mode equilibrium tests were carried out with a tenfold diluted (1mmol/L) copper (II) solution.

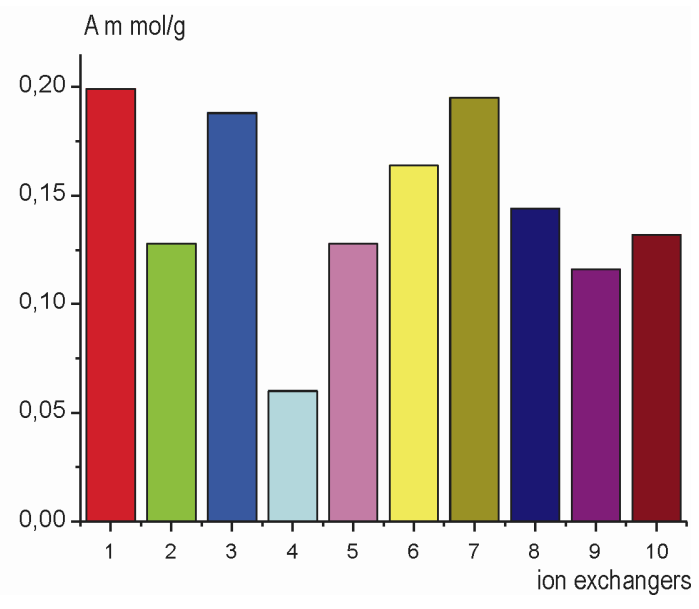

Fig 4. Sorption capacity (A) of sorbents tested for copper (II) ions at initial solution concentration of $1 \mathrm{mmol} / \mathrm{L}$

The sorption capacities of various ion exchangers reached in this test are not quite different and are of a comparable value as can be seen from Fig 3. At a low initial solution concentration a high degree of copper (II) removal was achieved (Table 4). However, the sorption of nonionic surfactant was not efficient for Purolite S940 and Purolite S950 chelating resins as well as for sulphonic one (Fig 5). It is noticeable that the concentration of the solution in this test was comparable with the value of cmc of nonionic surfactant.

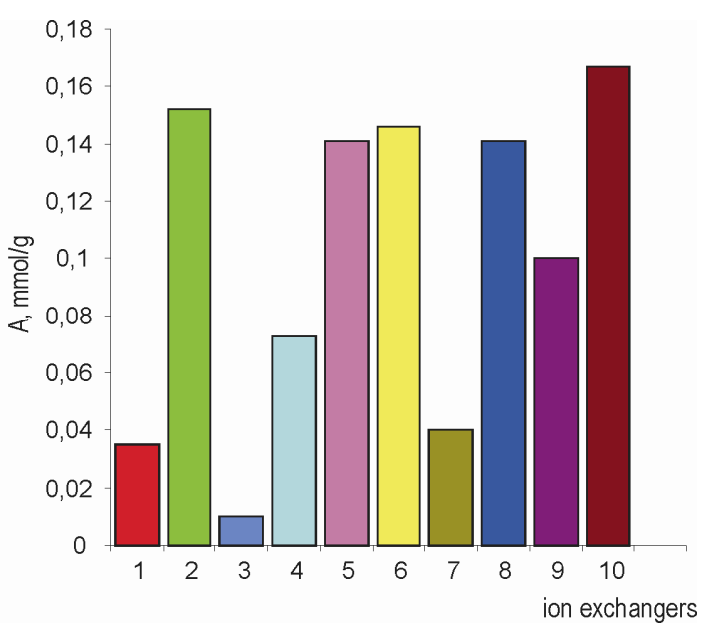

Fig 5. Sorption capacity (A) of sorbents tested for the nonionic surfactant Lutensol AO-10 from equimolar mixture of copper (II) and nonionic surfactant at initial solution concentration of $1 \mathrm{mmol} / \mathrm{L}$ 
Table 4. Degree of copper (II) removal from diluted solution $(1 \mathrm{mmol} / \mathrm{L})$

\begin{tabular}{c|c|c}
\hline Sorbent & Commercial name & Degree of removal (\%) \\
\hline 1 & Purolite C160 & 99,5 \\
\hline 2 & $\begin{array}{c}\text { Activated carbon } \\
\text { AC-20 }\end{array}$ & 64,0 \\
\hline 3 & Purolite S940 & 94,0 \\
\hline 4 & Purolite A420S & 38,0 \\
\hline 5 & Purolite C115E & 64,0 \\
\hline 6 & Purolite C107E & 82,0 \\
\hline 7 & Purolite S950 & 99,5 \\
\hline 8 & Purolite C104 & 72,0 \\
\hline 9 & Purolite S920 & 58,0 \\
\hline 10 & Purolite C106 & 66,0 \\
\hline
\end{tabular}

On the other hand, the sorption capacity of cation exchangers with carboxylic functional groups is surprising. Activated carbon demonstrates sharply increased sorption capacity with decreased initial nonionic surfactant Lutensol AO-10 concentration. About $80 \%$ of contaminant nonionic surfactant can be removed from diluted solutions $(1 \mathrm{mmol} / \mathrm{L})($ Table 5$)$.

Table 5. Degree of nonionic surfactant Lutensol AO-10 removal from solutions with copper (II) ions at initial solution concentration of $1 \mathrm{mmol} / \mathrm{L}$

\begin{tabular}{c|c|c}
\hline Sorbent & Commercial name & Degree of removal (\%) \\
\hline 1 & Purolite C160 & 17,5 \\
\hline 2 & $\begin{array}{c}\text { Activated carbon } \\
\text { AC-20 }\end{array}$ & 76,0 \\
\hline 3 & Purolite S940 & 5,0 \\
\hline 4 & Purolite A420S & 36,3 \\
\hline 5 & Purolite C115E & 70,5 \\
\hline 6 & Purolite C107E & 73,0 \\
\hline 7 & Purolite S950 & 20,0 \\
\hline 8 & Purolite C104 & 70,5 \\
\hline 9 & Purolite S920 & 50,0 \\
\hline 10 & Purolite C106 & 83,5 \\
\hline
\end{tabular}

Microscopic technique is very helpful in visualizing the kinetics of ion exchange [9]. The reaction front moving towards the centre of the particle can be seen clearly in Fig 6. The resin bead exhibits a characteristic color of hydrated copper (II) ions. The change with time of the position of the reaction front indicates consecutive stages of ion exchange. After $1 \mathrm{~min}$ time interval there were copper ions in the outer layer of the particle, and an unreacted area in the middle of the sphere was detected. Finally, after attainment of equilibrium the distribution of copper (II) throughout the particle was achieved. The amount of copper (II) taken up by Purolite C107E cation exchanger increased rapidly within $15 \mathrm{~min}$, and the sorption was virtually completed within $30 \mathrm{~min}$ (Fig 7).

The initial work reported here was carried out to screen and identify the best commercial ion exchangers for sorption of copper (II) and nonionic surfactant Lutensol AO-10.The study has shown that some of them are efficient sorbents for nonionic surfactant as well as for copper (II) ions. However, the sorption properties are strongly dependent on the sorption conditions, and they are influenced by the composition of the solution. The resin loading capacity in relation to the $\mathrm{pH}$ of the solution must be evaluated for a full characterization of the process.

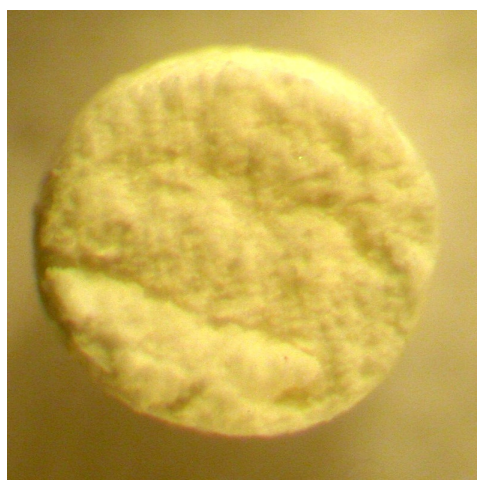

a

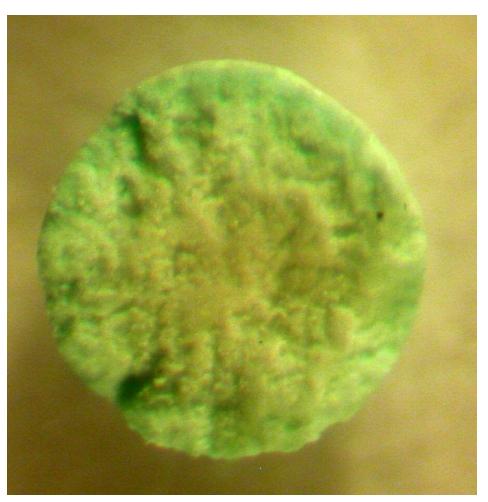

b

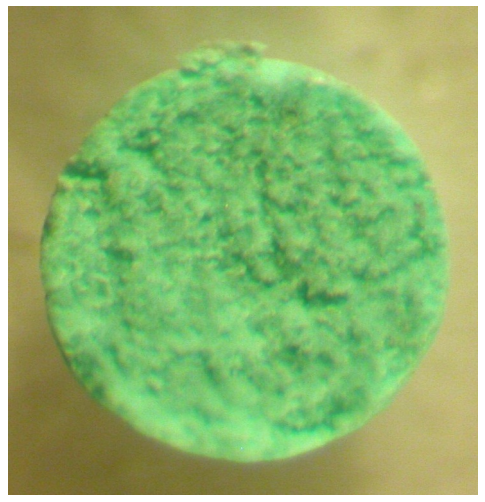

c

Fig 6. Microscopic analysis of the cross-section of the bead of Purolite C107E ion exchanger: a - before sorption; $\mathrm{b}$ - after $1 \mathrm{~min}$; $\mathrm{c}$ - after attainment of equilibrium 


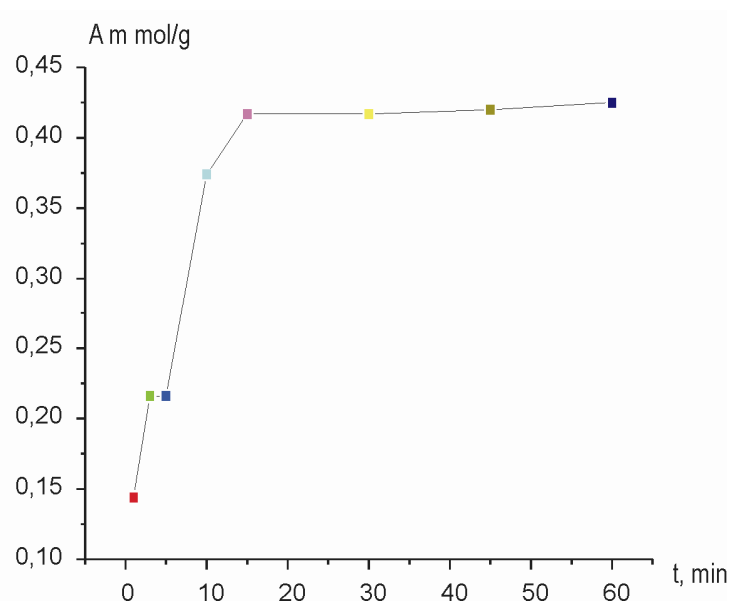

Fig 7. Sorption of copper (II) by Purolite C107E ion exchanger as a function of time at initial solution concentration of $10 \mathrm{mmol} / \mathrm{L}$

\section{Conclusions}

1. The highest copper (II) sorption capacities were determined for Purolite S950, Purolite S940 chelating resins and for Purolite $\mathrm{C} 160$ strong acid cation exchanger. The highest amounts of nonionic surfactant Lutensol AO10 were removed by Purolite C115E, Purolite C107E and Purolite C106 weak acid cation exchangers.

2. The presence of Lutensol AO-10 in the solution did not significantly affect the sorption of copper (II).

3. The sorption of copper (II) by Purolite C107E cation exchanger was very rapid during the first $15 \mathrm{~min}$ followed by a slower process. The equilibrium was achieved within $30 \mathrm{~min}$.

4. There is a possibility to remove nonionic surfactant and copper ions simultaneously by using weak acid cation exchangers in hydrogen form. The Purolite C107E cation exchanger would be the best choise.

\section{References}

1. Mulligan, C. N.; Yong, R. N.; Gibbs, B. F. Heavy metal removal from sediments by surfactants. Journal of Hazardous Materials, 2001, Vol 85, p 111 - 125.

2. Sandbacka, M.; Christianson, I.; Isomaa, B. The acute toxicity of surfactants on fish cells, Daphnia magna and fich-A comparative study. Toxicology in Vitro, 2000, Vol 14, Iss 1, p 61-68.

3. Adak, A.; Bandyopadhyay, M.; Pal, A. Removal of anionic surfactant from wastewater by alumina: acase study. Colloids and Surfaces, 2005, Vol 254, p 165-171.

4. Barrachina, S. M.; del Valle, M.; Matia, L.; Prats, R., Alonso, J. Potentiometric flow injection system for the determination of polyethoxylate nonionic surfactants using tubular ion-selective electrodes. Analytica Chimica Acta, 2001, Vol 438, p 305-313.
5. Klimenko, N.; Winther-Nielsen, M.; Smolin, S.; Nevynna, L.; Sydorenko, J. Role of the physico-chemical factors in the purification process of water from surface-active matter by biosorption. Water Research, 2002, Vol 36, p 5132-5140.

6. Lukascyk, J.; Lękawska, E.; Lunkwitz, K.; Petzold, G. Sorbents for Removal Surfactants from Aqueous Solutions. Journal of Applied Polymer Science, 2004, Vol 92, p 1510-1515.

7. Lukascyk, J.; Lękawska, E.; Zielinska, E. Synthesis and evaluation of cationic and cationogenic polymeric sorbents for removing surfactants from aqueous solutions. Macromol. Symp., 2001, Vol 164, p 247-256.

8. Charerntanyarak, L. Heavy metals removal by chemical coagulation and precipitation. Water Science and Technology, 1999, Vol 39, Iss 10-11, p 135-138.

9. Bakkaloglu, I.; Butter, T. J.; Evison, L. M. Screening of various types biomass for removal and recovery of heavy metals by biosorption, sedimentation and desorption. Water Science and Technology, 1998, Vol 38, Iss 6, p 269277.

10. Ngah, W. S. W.; Endud, C. S.; Mayanar, R. Removal of copper (II) ions from aqueous solution onto chitosan and crosslinked chitosan beads. Reactive and Functional Polymers, 2002, Vol 50(2), p 181-190.

11. Pesavento, M.; Profumo, A.; Alberti, G.; Conti, P. Adsorption of lead (II) and copper (II) by activated carbon by complexation with surface functional groups. Analytica Chimica Acta, 2003, Vol 480, p 171-180.

12. Dabrovsky, A.; Hubicki, Z.; Podkoscielny, P.; Robens, E. Selective removal of the heavy metal ions from waters and industrial wasterwaters by ion - exchange method. Chemosphere, 2004, Vol 56, Iss 2, p 91-106.

13. Saito, S. Properties of Nonionic Surfactant-Polymethacrylic Acid Complexes: Comparison with the Polyacrylic Acid Complexes. Journal of Colloid and Interface Science, 1994, Vol 165, Iss 2, p 505-511.

14. Snukiškis, J.; Gefenienè, A.; Kaušpèdienè, D. Cosorption of metal $(\mathrm{Zn}, \mathrm{Pb}, \mathrm{Ni})$ cations and nonionic surfactant (alkylmonoethers) in polyacrylic acid-functionalized cationexchanger. Reactive and Functional Polymers, 2000, Vol 46, p 109-116.

15. Shonfeldt, N. Grenzflacheractive Athylene-Addukte ihre Herrstellung, Eigenschaften, Anwendung und Analyse. Wissenschaftliche Verlagsgeselschaft, Stutgart, 1976.

16. Lur'e, Yu. Handbook on Analytical Chemistry. Moscow, Khimiya, 1979.

17. Okada, T. Complexation of Poly(oxyethylene) in Analytical Chemistry. Analyst, 1993, Vol 118, p 959-971.

18. Schott, H. Effect of Inorganic Additives on Solutions of Nonionic Surfactants. Journal of Colloid and Interface Science, 1995, Vol 173, Iss 2, p 265-277. 


\section{Cu (II) JONŲ IR NEJONINIŲ PAVIRŠINIO AKTYVUMO MEDŽIAGŲ (PAM) SORBCIJA JONITAIS IR AKTYVINTĄJA ANGLIMI}

\section{R. Jancevičiūtè, A. Gefenienè}

S antrauka

Jonitai, plačiai naudojami vario (II) jonams iš nuotekų šalinti, gali sorbuoti ir nejonines paviršinio aktyvumo medžiagas (NPAM), kurios neretai patenka ị nuotekas po ịvairių gamybinių procesų kartu su vario jonais. Laboratorinėmis sąlygomis tiriant pusiausvirają vario jonu ir NPAM Lutensol AO-10 sorbciją i̇vairių tipu jonitais ir aktyvintaja anglimi buvo nustatyta, kad didžiausia geba sulaikyti vario jonus būdinga chelatiniam jonitui Purolite S950. Didžiausias giminingumas nejoninei PAM būdingas karboksiliniams katijonitams. Bendrai vario (II) jonų ir NPAM sorbcijai geriausiai tiktų silpnai rūgštinis katijonitas Purolite C107E. Kinetiniai šio jonito tyrimai leidžia daryti išvadą, kad vario jonu sorbcija vyksta greitai, ir pusiausvyra nusistovi per 30 min. Mažèjant vario jonų koncentracijai tirpale skirtumai tarp įvairių jonitų sorbcinès gebos mažeja. Nejoninès PAM Lutensol AO-10 įtaka vario jonų sorbcijai yra nežymi.

Reikšminiai žodžiai: jonitas, aktyvintoji anglis, sorbcija, varis, nejoninė paviršinio aktyvumo medžiaga (NPAM), išvalymo laipsnis.

\section{СОРБЦИЯ МЕДИ (II) И НЕИОННЫХ ПОВЕРХНОСТНО-АКТИВНЫХ ВЕЩЕСТВ С ПОМОЩЬЮ ИОНИТОВ И АКТИВИРОВАННОГО УГЛЯ}

\section{Р. Янцевичюте, А. Гефенене}

Резюме

Иониты, широко используемые для устранения ионов меди (II) из сточных вод, способны сорбировать и неионные поверхностно-активные вещества (НПАВ), которые после многих производственных процессов переходят в сточные воды совместно с ионами меди (II). Исследования равновесной сорбции меди (II) и НПАВ с помощью разных типов ионитов и активированного угля в лабораторных условиях показали, что наивысшей сорбционной емкостью отличается хелатный ионит Purolite S950. Наивысшим сродством к НПАВ отличаются карбоксильные катиониты. Наиболее приемлемым ионитом для совместной сорбции меди (II) и НПАВ можно считать слабокислотный катионит Purolite C107E. Исследование кинетики сорбции меди (II) этим катионитом показало, что сорбция меди (II) отличается быстротой, и равновесие достигается в течение 30 минут. При снижении концентрации меди (II) в растворе различия между сорбционной емкостью разных ионитов снижаются. Установлено, что влияние НПАВ на сорбцию меди (II) незначительно.

Ключевые слова: ионит, активированный уголь, сорбция, неионное поверхностно-активное вещество, медь, степень очистки.

Renata JANCEVIČIŪTĖ. Master student (chemistry), Dept of Chemistry, Vilnius Pedagogical University (VPU).

Bachelor of Science (chemistry), VPU, 2005. Research interests: sorption processes, pollution prevention.

Audronė GEFENIENĖ. Dr, Assoc Prof, Dept of Chemistry, Vilnius Pedagogical University (VPU); research worker, Dept of Environmental Chemistry, Institute of Chemistry.

Doctor of Science (physical sciences), Vilnius University and Institute of Chemistry, 2000. Employment: Associate Professor (2004), lecturer (2003),Vilnius Pedagogical University; research worker (1983), Institute of Chemistry. Publications: author of over 30 research papers. Research interests: sorption processes, physical and chemical properties of ion exchangers, pollution prevention. 